\title{
RELATIONSHIP OF KNOWLEDGE AND ATTITUDE WITH HEALTH CENTER OFFICERS' PREPAREDNESS INFACING EARTHQUAKE DISASTERS HEALTH
}

\author{
Devi Listiana ${ }^{1}$, Fatima Nuraini Sasmita ${ }^{2}$, Andika Satria ${ }^{3}$ \\ ${ }^{123}$ Program Studi Sarjana S1 Keperawatan Stikes Tri Mandiri Sakti \\ Bengkulu
}

Email: devilistiana01@gmail.com

\begin{abstract}
The earthquake caused problems in the health sector, so that strategic steps to minimize this impact included the knowledge and attitudes of puskesmas officers. The purpose of the study was to study the relationship between knowledge and attitudes with the preparedness of puskesmas officers to face earthquakes at Telaga Dewa Health Center, Bengkulu City. The research method uses an analytical survey design with a cross sectional approach. The population in this study were all puskesmas officers at Telaga Dewa Health Center Bengkulu City as many as 70 people with total sampling. Data analysis was carried out by univariate and bivariate, bivariate analysis using Chi-Square test and using the Contingency Coefficient test. The results of the study of the knowledge variable obtained the following results the value of asymp.sig $(p)=0.002$. Because $p$ value $<0.05$, it means that there is a relationship between knowledge and preparedness of puskesmas officers in dealing with earthquake disasters. The attitude variable was obtained with the following results asymp.sig $(p)=0.007$. Because $p$ value $<0.05$, it means that there is a relationship between attitude and preparedness of puskesmas officers in dealing with earthquake disasters. It can be concluded that the better the knowledge and attitude, the more prepared and alert a person is in dealing with earthquakes. It is hoped that the Health Service of the Telaga Dewa Health Center in Bengkulu City, especially the Puskesmas officers, can provide training to puskesmas officers on disaster response.
\end{abstract}

\section{Keywords: Knowledge, Attitude, Earthquake Preparedness}

\section{PENDAHULUAN}

Gangguan (disruptif) terhadap berlangsungnya peradaban secara serius, gangguan tersebut meliputi kerugian dan dampak buruk terhadap kemanusiaan, material, ekonomi dan lingkungan, gangguan ini melebihi kemampuan masyarakat yang terdampak bencana, dalam menanganinya dengan sumberdaya yang dimiliki (Heryana, 2020). Bencana merupakan suatu gangguanserius terhadap masyarakat 
yang menimbulkan kerugian secara meluas dan dirasakan baik oleh masyarakat, dimana dampak yang ditimbulkan melebihi kemampuan manusia (Wijayanto, 2012). Mengatakan bahwa Indonesia merupakan salah satu negera yang rentan dengan berbagai bencana, baik dari aspek geologisnya, klimatologis, maupun sosial demografisnya. Dimana Indonesia berada pada peringkat 37 dari 180 negara paling rentan bencana baik bencana alam maupun bencana yang diakibatkan oleh manusia itu sendiri (Nasional et al., n.d.) .Gempa bumi merupakan bencana alam yang cukup sering terjadi di Indonesia. Dalam kurun waktu 10 tahun terakhir (2009-2019) bencana alam gempa bumi telah terjadi sebanyak 216 kali dengan jumlah korban hilang dan meninggal dunia sebanyak 637 jiwa, 8.687 korban luka-luka, 459.855 pengungsi, 602.223 unit rumah warga rusak serta 131 fasilitas umum yang juga mengalami kerusakan (BNPB, 2019).

Pulau Sumatera merupakan wilayahyang rawan gempa bumi dan berpotensi menghadapi ancaman gempa besar dari banyak sumber (BMKG, 2007). Kota Bengkulu adalah salah satu bagian dari Provinsi Bengkulu yang rawan bencana. Berdasarkan letak dan lokasinya bahwa Kota Bengkulu berada diantara patahan Sumatera dan subdukasi Lempeng Tektonik Indo-Australia dan lempeng Tektonik Eurasia, Kota Bengkulu juga berada di lereng bukit barisan yang seluruh gunungnya aktif serta memiliki pantai dengan panjang 12 kilo meter. Gempa yang terjadi pada tahun 2000- 2007, menjadi pusat perhatian dunia karena banyaknya kerusakan gedung- gedung, perkantoran, rumah-rumah penduduk, sekolah-sekolah bahkan kecacatan dan kematian pada anak-anak sampai usia lanjut (Yustisia et al., 2019)

Menurut sejarah yang ada Provinsi Bengkulu telah beberapa kali digoncang gempa besar seperti pada tanggal 24November 1833 (VIII-IX $\quad$ MMI), 18 Agustus 1938 (VII MMI), 18 Agustus 1871 (VI-VII MMI), 26 Juni 1914 (VII- VIII MMI), 24 Nopember 1933 (VIII- IX MMI) dan 15 Desember 1979 (VIII MMI) (BMKG, 2007). Berdasarkan data dari ESDM Provinsi Bengkulu menyebutkan lokasi rawangempa di Kota Bengkulu dibagi dalam beberapa zona yaitu: Zona A (Lemah) meliputi wilayah Pasar Berkas, Penurunan, Padang 
Harapan, Pagar Dewa, dan Lempuing. Zona B (Sedang) meliputi wilayah Kandang Limun, Kampung Bali, Suka Merimdu, Sawah Lebar, Betungan, Surabaya, Tanjung Agung dan Air Sebakul. Zona C (Kuat) meliputi wilayah Pematang Gubernur, Nakau dan Bentiring (Dinas ESDM Provinsi Bengkulu, 2003). Gempa bumi dengan skala besar pertama kali terjadi di Bengkulu pada tanggal 11 Desember 1681, kemudian terjadi lagi 3 November 1756, tahun 1770, 18 Maret 1818, 24 November 1883, 27 Juni 1902, 15 Desember 1979 dan 4 Juni 2000, dan gempa besar terakhir terjadi 12 September 2007 (Bapeda Provinsi Bengkulu, 2012).

Kejadian bencana gempa bumi ini tidak hanya menimbulkan korban jiwa tetapi juga dapat menimbulkan permasalahan-permasalahan baik di bidang kesehatan, ekonomi, lingkungan, air bersih, pertanian. Oleh karena itu diperlukan langkahlangkah strategis untuk menimalkan dampaknya. Salah satu upaya dapat dilakukan dengan menyiapkan kesiapsiagaan petugas pukesmas diwilayah tersebut (Mawan, 2019). Penerapan kesiapsiagaan bencanatidak hanya melibatkan pemerintah, tetapi juga melibatkan masyarakat, terutama bagipetugas kesehatan. Sebagai salah satu komponen yang penting dalam respon penanganan bencana, perawat dan petugas kesehatan dipuskesmas memiliki peran yang sangat besar. Kegagalan peran dan tanggungjawab perawat dan petugas kesehatan di puskesmas berdampak kegagalan dalam menangani korban bencana. Maka selain perawat dan petugas kesehatan ahli dalam bidangnya, perawat dan petugas kesehatanjuga harus mengetahui bagaimana kesiapsiagaan bencana diterapkan sehingga bisa meminimalisir risikobencana dan memperbesar keberhasilan penanganan korban bencana (Husna, 2012).

Kegiatan dari kesiapsiagaan bencana adalah membentuk suatu bagian yang tak terpisahkan dalam sistem nasional yang bertanggung jawab untuk mengembangkan perencanaan dan program pengelolaan bencana yang meliputi: pencegahan, mitigasi, kesiapsiagaan, respon, rehabilitasi atau rekontruksi (Nurdin, 2017). Maka petugas kesehatan harus memiliki pengetahuan yang baik untuk mengembangkan kebijakan dalamkebencanaan, perencanaan secara menyeluruh, melaksanakan pelatihan, simulasi kesiapsiagaan bencana dan tanggap darurat. 
Menurut PPNI (2013), menjelaskan pengetahuan adalah suatu hasil dari rasa keingintahuan melalui proses sensoris, terutama pada mata dan telinga terhadap objek tertentu. pengetahuan atau kognitif merupakan domain yang sangat penting untuk terbentuknya tindakan seseorang (overt behavior) (Notoatmodjo, 2013). Selain pengetahuan, yang harus dimiliki juga oleh perawat dan petugas kesehatan yaitu sikap. Sikap dapat juga diartikan sebagai kecenderungan untuk berespons (secara positif dan negatif) terhadap orang, objek, atau situasi tertentu (Sarwono 2012). Teori Tindakan Beralasan (Theori of Reasoned Action) Saifuddin (2005), yang mengatakan bahwa sikap mempengaruhi perilaku lewat suatu proses pengambilan keputusan dan dalam hal ini adalah keputusan perawat untuk melakukan kesiapsiagaan dari bencanagempa bumi tersebut.

Data petugas Puskesmas Telaga DewaKota Bengkulu, sebanyak 70 orang terdiri dari KA Puskesmas 1 orang, Dokter 3 orang, Perawat 17 orang, Bidan 27 orang, Apoteker 2 orang, Laboratorium Kesehatan 1 orang, Kesehatan Masyarakat 3 orang, KA Tata Usaha 1 orang, Nutritionis 2 orang, Petugas Kesling 2 orang, Fungsional Umum 1 orang, Honor 7 orang, TKS (Tenaga Kerja Swasta) 3 orang. Dari hasil survey awal melalui wawancara, penulis memperoleh informasi dari salah satu petugas Puskesmas Telaga Dewa Kota Bengkulu bahwa Puskesmas Telaga Dewa Kota Bengkulu jarang adanya pelatihan- pelatihan kesiapsiagaan bencana. Baik itu dilakukan secara mandiri ataupun kerjasama dengan BNPB, Basarnas. Kemudian posisi Puskesmas Telaga Dewa Kota Bengkulu sangat strategis apabila terjadi bencana, terutama gempa bumi. Dikarenakan, posisi Puskesmas Telaga Dewa Kota Bengkulu terletak diantara dua perguruan tinggi, yang tentunya banyak mahaiswa di dalam perguruan tinggi tersebut Sehingga perlunya peran aktif dari Puskesmas Telaga Dewa Kota Bengkulu apabila terjadi gempa di daerah sekitar Puskesmas Telaga Dewa Kota Bengkulu. Dinas Kesehatan Kota Bengkulu menjelaskan, bahwa Puskesmas Telaga Dewa belum memiliki Satuan Tugas (SATGAS) Penanggulangan Krisis Kesehatan dan Tim Reaksi Cepat. Dikarenakan bahwa Puskesmas TelagaDewa Kota Bengkulu masih kurang keperduliannya terhadap kesiapsiagaan bencana. Tujuan penelitian ini adalah untuk mengetahui hubungan pengetahuan dan sikap dengan kesiapsiagaan 
petugas puskesmas dalam menghadapi adanya bencana gempa bumi di wilayah Puskesmas Telaga Dewa Kota Bengkulu.

\section{METODE PENELITIAN}

Lokasi penelitian dilakukan di Wilayah Puskesmas Telaga Dewa Kota Bengkulu pada tanggal 07 Juni - 07 Juli 2021. Populasi dalam penelitian ini adalah keseluruhan petugas yang ada diPuskesmas Telaga Dewa Kota Bengkulu. Sampel dalam penelitian ini sebanyak 70 orang petugas, cara pengambilan sampel dengan mengunakan teknik Total Sampling. Pengumpulan data dengan data primer yang diperoleh dari wawancara langsung dengan responden menggunakan kuesioner mengenai pengetahuan, sikap dan kesiapsiagaan petugas puskesmas dalam menghadapi bencana gempa bumidi Puskesmas Telaga Dewa Kota Bengkulu. Teknik analisis data dengan analisis univariat dan bivariate dengan uji Chi Square dan Contingensi Coefficient.

\section{HASIL PENELITIAN}

\section{Analisis Univariat}

Tabel 1. Distribusi Frekuensi Pengetahuan Petugas Puskesmas Dalam Menghadapi BencanaGempa Bumi Di Wilayah Puskesmas Telaga Dewa Kota Bengkulu

\begin{tabular}{clcc}
\hline No & Pengetahuan & Frekuensi & Presentase (\%) \\
\hline 1 & Kurang & 6 & 8.6 \\
2 & Cukup & 30 & 42.9 \\
3 & Baik & 34 & 48.6 \\
\hline & & 70 & 100.0 \\
\hline
\end{tabular}

Pada tabel 1 dapat dilihat bahwa 70 petugas yang diteliti di puskesmas telaga dewa kota Bengkulu, 6 petugas $(8,6 \%)$ menilai pengetahuannya kurang, kemudian 30 petugas $(42,9 \%)$ menilai pengetahuannya cukup, selanjutnya sisapetugas ada 34 orang $(48,6 \%)$ menilai pengetahuannya baik. 
Tabel 2. Distribusi Frekuensi Sikap Petugas Puskesmas Dalam Menghadapi Bencana Gempa Bumi Di Wilayah Puskesmas Telaga Dewa Kota Bengkulu

\begin{tabular}{llll}
\hline No & Sikap & Frekuensi & Presentase (\%) \\
\hline 1 & Unfavourable & 18 & 25.7 \\
\hline 2 & Favourable & 52 & 74.3 \\
\hline & Total & 70 & 100.0
\end{tabular}

Pada tabel 2 dapat dilihat bahwa 70 petugas yang diteliti di puskesmas telaga dewa kota Bengkulu, 18 orang (25,7\%) menilai Unfavourable, sedangkan 52 orang (74,3\%) menilai Favourable.

Tabel 3. Distribusi Frekuensi Kesiapsiagaan Petugas Puskesmas Dalam Menghadapi Bencana Gempa Bumi Di Wilayah Puskesmas Telaga Dewa Kota Bengkulu

\begin{tabular}{llll}
\hline No & Kesiapsiagaan & Frekuensi & Persentase (\%) \\
\hline 1 & Rendah & 22 & 31.4 \\
\hline 2 & Sedang & 25 & 35.7 \\
\hline 3 & Tinggi & 23 & 32.9 \\
\hline & Total & 70 & 100.0 \\
\hline
\end{tabular}

Pada tabel 3 dapat dillihat bahwa 70 petugas yang diteliti di puskesmas telaga dewa kota Bengkulu, 22 petugas $(31,4 \%)$ menilai rendah, kemudian sebanyak 25 petugas $(35,7 \%)$ menilai sedang, sedangkan 23 petugas $(32,9 \%)$ menilai tinggi.

\section{Analisis Bivariat}

Hubungan Pengetahuan Dengan Kesiapsiagaan Petugas Puskesmas Dalam Menghadapi Bencana Gempa Bumi Di Puskesmas Telaga Dewa Kota Bengkulu.

Tabel 4. Hubungan Pengetahuan Dengan Kesiapsiagaan Petugas Puskesmas Telaga Dewa Kota Bengkulu

\begin{tabular}{|c|c|c|c|c|c|c|c|c|c|c|c|}
\hline \multirow[t]{3}{*}{ Pengetahuan } & \multicolumn{6}{|c|}{ Kesiapsiagaan } & \multirow{2}{*}{\multicolumn{2}{|c|}{ Total }} & \multirow[t]{3}{*}{$\mathbf{X}^{2}$} & \multirow[t]{3}{*}{$\mathbf{P}$} & \multirow[t]{3}{*}{$\mathbf{C}$} \\
\hline & \multicolumn{2}{|c|}{ Rendah } & \multicolumn{2}{|c|}{ Sedang } & \multicolumn{2}{|c|}{ Tinggi } & & & & & \\
\hline & $\mathrm{F}$ & $\%$ & $\mathrm{~F}$ & $\%$ & $\mathrm{~F}$ & $\%$ & $\mathrm{~F}$ & $\%$ & & & \\
\hline Kurang & 5 & 83,3 & 0 & 0 & 1 & 16,7 & 6 & 100 & & & \\
\hline Cukup & 7 & 23,3 & 17 & 56,7 & 6 & 20 & $\begin{array}{l}3 \\
0\end{array}$ & 100 & $\begin{array}{l}17.13 \\
2\end{array}$ & 0.002 & 0.443 \\
\hline Baik & 10 & 29,4 & 8 & 23,5 & $\begin{array}{l}1 \\
6 \\
\end{array}$ & 47,1 & $\begin{array}{l}3 \\
4 \\
\end{array}$ & 100 & & & \\
\hline & Total & & & & & & $\begin{array}{l}7 \\
0\end{array}$ & 100 & & & \\
\hline
\end{tabular}


Pada tabel 4 dapat dilihat bahwa di Puskesmas Telaga Dewa Kota Bengkulu, dari 6 orang petugas dengan pengetahuan kurang, terdapat 5 orang $(83,3 \%)$ yang memiliki kesiapsiagaan rendah, sedangkanpetugas memiliki kesiapsiagaan sedang sebanyak $0(0 \%)$, dan 1 orang $(16,7 \%)$ lainnya memiliki kesiapsiagaan tinggi. Berikutnya dari 30 orang petugas yang pengetahuannya cukup, terdapat 7 orang $(23,3 \%)$ dengan kesiapsiagaan rendah, 17 orang $(56,7 \%)$ dengan kesiapsiagaan sedang, dan 6 orang (20\%) dengan kesiapsiagaan tinggi. Selanjutnya dari 34 orang yang pengetahuannya baik, terdapat 10 orang $(29,4 \%)$ dengan kesiapsiagaanrendah, 8 orang $(23,5 \%)$ dengan kesiapsiagaan sedang, dan 16 orang $(47,1 \%)$ dengan kesiapsiagaan tinggi.

Pada uji hubungan pengetahuan dengan kesiapsiagaan petugas Puskesmas Telaga Dewa Kota Bengkulu diperoleh nilai statistik Chi-square di dapat nilai $\mathrm{X}^{2}$ $=17.132$ dan nilai asymp.sig $(p)=0,002$. Karena nilai $\mathrm{p}<0,05$ maka $\mathrm{H} 0$ ditolak Ha diterima artinya ada hubungan pengetahuan dengan kesiapsiagaan petugas puskesmas dalam menghadapi bencana gempa bumi di Puskesmas Telaga Dewa Kota Bengkulu.

Pada uji keeratan hubungan pengetahuan dengan kesiapsiagaan petugas puskesmas dalam menghadapibencana gempa bumi di wilayah Puskesmas Telaga Dewa Kota Bengkulu diperoleh nilai Contingency Coefficient (C). Nilai $\mathrm{C}=$ 0,443. Karena $\mathrm{C}=0,443$ nilai tersebut tidak terlalu jauh dari nilai $\mathrm{C}_{\max }=0,70$ maka dapat disimpulkan bahwa keeratan hubungan pengetahuan dengan kesiapsiagaan petugas dalam menghadapi bencana gempa bumi di Puskesmas Telaga Dewa Kota Bengkulu, hubungan tersebut dengan kategori cukup erat.

Hubungan Sikap Dengan Kesiapsiagaan PetugasPuskesmas Dalam Menghadapi Bencana Gempa Bumi Di Puskesmas Telaga Dewa Kota Bengkulu 
Tabel 5. Hubungan Sikap Dengan Kesiapsiagaan Petugas Puskesmas Telaga Dewa Kota Bengkulu

\begin{tabular}{|c|c|c|c|c|c|c|c|c|c|c|c|}
\hline \multirow[t]{3}{*}{ Sikap } & \multicolumn{6}{|c|}{ Kesiapsiagaan } & \multirow{2}{*}{\multicolumn{2}{|c|}{ Total }} & \multirow{3}{*}{\multicolumn{2}{|c|}{$\mathbf{X}^{2} \mathbf{P}$}} & \multirow[t]{3}{*}{$\mathbf{C}$} \\
\hline & \multicolumn{2}{|c|}{ Rendah } & \multicolumn{2}{|c|}{ Sedang } & \multicolumn{2}{|c|}{ Tinggi } & & & & & \\
\hline & $\bar{F}$ & $\%$ & $\mathrm{~F}$ & $\%$ & $\mathrm{~F}$ & $\%$ & $\mathrm{~F}$ & $\%$ & & & \\
\hline Unfavorable & 11 & 61,1 & 4 & 22,2 & 3 & 16,7 & 18 & 100 & 9.961 & 0.007 & 0.353 \\
\hline Favorable & 11 & 21,2 & 21 & 40,4 & 20 & 38,5 & 52 & 100 & & & \\
\hline & & & & & & Total & 70 & 100 & & & \\
\hline
\end{tabular}

Pada tabel 5 dapat dilihat, bahwa di Puskesmas Telaga Dewa Kota Bengkulu, dari 18 orang petugas dengan sikap Unfavorable, terdapat 11 orang $(61,1 \%)$ yang memiliki kesiapsiagaan rendah, sebanyak 4 orang $(22,2 \%)$ petugas dengan kesiapsiagaan sedang, dan 3 orang (16,7\%) lainnya memiliki kesiapsiagaan tinggi. Berikutnya dari 52 orang yang merasa sikap favorable, terdapat 11 orang $(21,2 \%)$ dengan kesiapsiagaan rendah, sedangkan 21 orang $(40,4 \%)$ dengan kesiapsiagaan sedang, dan 20 orang (38,5\%) dengan kesiapsiagaan tinggi.

Pada uji hubungan sikap dengan kesiapsiagaan petugas Puskesmas Telaga Dewa Kota Bengkulu diperoleh statistikChi-square di dapat nilai $\mathrm{X}^{2}=.9 .961$ dan nilai asymp.sig $(\mathrm{p})=0,007$. Karena nilai $\mathrm{p}<0,05$ maka $\mathrm{H} 0$ ditolak Ha diterima artinya ada hubungan pengetahuan dengan kesiapsiagaan petugas puskesmas dalam menghadapi bencana gempa bumi di Puskesmas Telaga Dewa Kota Bengkulu.

Pada uji keeratan hubungan sikap dengan kesiapsiagaan petugas puskesmas dalam menghadapi bencana gempa bumi di pada petugas Puskesmas Telaga Dewa Kota Bengkulu dapat diperoleh nilai Contingency Coefficient (C). Nilai C $=0,35$. Karena $\mathrm{C}=0,353$ nilai tersebut tidak terlalu jauh dari nilai $\mathrm{C}_{\max }=0,70$ maka dapat disimpulkan bahwa keeratan hubungan sikap dengan kesiapsiagaan petugas dalam menghadapi bencana gempa bumi di Puskesmas Telaga Dewa Kota Bengkulu, hubungan tersebut adalah kategori cukup erat. 


\section{PEMBAHASAN}

\section{Gambaran Pengetahuan Petugas Puskesmas Dalam Menghadapi Bencana Gempa Bumi}

Berdasarkan hasil penelitian, bahwa dari 70 orang petugas Puskesmas Telaga Dewa Kota Bengkulu didapatkan 6 petugas $(8,6 \%)$ kurang, kemudian 30 petugas $(42,9 \%)$ cukup, 34 orang $(48,6 \%)$ baik.

Penelitian ini tidak sejalan dengan penelitian yang dilakukan Indri (2020), mengenai "gambaran pengetahuan dan sikap perawat tentang kesiapsiagaan pelayanan kesehatan dalam menghadapi bencana banjir" disimpulkan Hasil penelitianmenampilkan bahwa 20 responden $(47,6 \%)$ memiliki pengetahuan baik dan 22 responden $(52,4 \%)$ memiliki pengetahuan yang kurang baik. Hal ini dapat disebabkan pada pendidikan seseorang, pendidikan yang semakin tinggi akan memberikan perubahan berupa pertambahan informasi serta perubahan pola pikir seseorang.

Berdasarkan penelitian yang dilakukan bahwa pengetahuan yang baik dimiliki oleh tenaga kesehatan yang didapat dari pendidikan dan masa kerja yang dimiliki. Hal ini didukung oleh Budi (2010), yang menyebutkan bahwa pengetahuan dapat juga diperoleh dengan pendidikan dan pengalaman, misalnya pengalaman tenaga kesehatan di dapat dari pergaulan dalam dunia kesehatan sehari-hari, tenaga kesehatan yang sering berpergian ke daerah lain untuk pelatihan tentang keperawatan.

\section{Gambaran Sikap Petugas Puskesmas Dalam Menghadapi Bencana Gempa Bumi}

Berdasarkan hasil penelitian, tampak bahwa dari 70 orang petugas puskesmas didapatkan 18 orang $(25,7 \%)$ menilai Unfavourable, sedangkan 52 orang $(74,3 \%)$ menilai Favourable. Kondisi ini menunjukkan sebagian besar petugas puskesmasmemiliki sikap yang baik dalam kesiapsiagaan menghadapi bencana. Dikarenakan rasa takut dan membayangkan dampak dari sebuah bencana gempa bumi yang dapat terjadi sewaktu-waktu tanpa dapat dikompromi dan dihindari. Akan tetapi masih terdapat 18 (25,7\%) orang petugas dengan sikap unfavorable petugas beranggapan bahwa respon secara cepat pada suatu kondisi darurat akibat adanya suatu bencana gempa merupakan 
tindakanyang tepat, petugas tidak menyadaribahwa persiapan atau kesiap siaga adalah lebih penting untuk menentukan sikap dalam menghadapi bencana gempa dibandingkan dengan hanya respon cepat saja, dengan persiapan sebelum terjadinya suatu bencana gempa maka akanmenciptakan mental siaga dan dapat melakukan tindakan yang terlatih, teratur dan, terarah. Penelitian ini sejalan dengan penelitian yang dilakukan oleh Pipin (2021), mengenai "kesiapsiagaan tenaga kesehatan dalam tanggap kegawatdaruratan bencana banjir di Puskesmas Tibawa Kabupaten Gorontalo" penelitian didapatkan sikap tenaga kesehatan yang paling banyak yaitu sikap baik sebanyak 65 orang $(94,2 \%)$ dan sikap tenaga kesehatan kurang sebanyak 4 orang (5,8\%). Sedangkan menurut penelitian Retno (2020), mengenai "analisis" faktor-faktor kesiapsiagaan masyarakat rawan bencana" dapat disimpulkan penelitian ini diperoleh bahwa responden yang bersikap positif cenderung siap dalam menghadapi bencana $(52,3 \%)$ sedangkan responden yang bersikap negatif cenderung kurang siap menghadapi bencana (70,7\%). Maka dapat diartikan penelitian yang dilakukan Retno berbanding terbalikdengan hasil di dalam penelitian ini.

\section{Gambaran Kesiapsiagaan Petugas Puskesmas Dalam Menghadapi Bencana Gempa Bumi}

Berdasarkan hasil penelitian dari 70 orang petugas puskesmas telaga dewa kota Bengkulu didapatkan kesiapsiagaan dalam mengadapi bencana gempa bumi 22 orang $(31,4 \%)$ rendah, 25 orang $(35,7 \%)$ sedang, dan 23 orang $(32,9 \%)$ tinggi.

Penelitian lain menurut Direja dan Susilo (2018), bahwa dari 84 orang tenaga kesehatan terdapat 14 orang $(16,7 \%)$ tidak siap menghadapi bencana gempabumi dan tsunami, 18 orang $(21,4 \%)$ cukup siap menghadapi bencana gempa bumi dantsunami, dan 52 orang $(61,9 \%)$ siap menghadapi bencana gempa bumi dan tsunami. Sedangkan penelitian lain yang dilakukan oleh Herman (2019) disimpulkan gambaran kesiapsiagaan tenaga kesehatan puskesmas di kecamatan Manggala kota Makassar sebagian besar menyatakan siapsiaga dalam penanggulangan bencana banjiryaitu sebanyak 37 orang (92,5\%) dan 3 orang (7,5\%) menyatakan tidak siapsiaga.

Jurnal Vokasi Keperawatan (JVK) Volume 4 No 2 Desember 2021 
Hal ini dikarenakan, jarangnya mengadakan pelatihan mengenai siap siaga bencana yang merupakan salah satu faktor yang menyebabkan kurangnya kesadaran petugas tentang pentingnya kewaspadaan dan kesiapan terhadap menghadapi bencana gempa bumi, serta pengetahuan untuk meningkatkan kesiapsiagaan terhadap bencana gempa bumi.

Sebagai pusat pelayanan kesehatan tingkat pertama seharusnya petugas puskesmas memiliki kesiapsiagaan yang tinggi, justruberbanding terbalik dengan kesiapsiagaan yang sedang, lebih tinggi daripada yang memiliki kesiapsiagaan tinggi, yaitu 25 orang $(35,7 \%)$. hal ini dikarenakan beban yang diberikan kepada puskesmas yang menaungi masyarakat padawilayah kerjanya, pengetahuan yang cukup diharapkan dapat ditularkan kepada masyarakat di wilayah kerjanya. Faktor lain yang menyebabkan Petugas puskesmas lalai dengan kesiapsiagaan terhadap bencana khususnya gempa bumi yaitubeban kerja petugas yang terlalu banyak, sibuk dengan pekerjaannya masing-masing, yang menyebabkan kurangnya kepedulian, dan sikap terhadap kesiapsiagaan bencana gempa bumi.

\section{Hubungan Pengetahuan Dengan Kesiapsiagaan Petugas Puskesmas Dalam Menghadapi Bencana Gempa Bumi}

Pada tabel 4 dapat dilihat bahwa di Puskesmas Telaga Dewa Kota Bengkulu, dari 6 orang petugas dengan pengetahuan kurang, terdapat 5 orang $(83,3 \%)$ yang memiliki kesiapsiagaan rendah, sedangkanpetugas memiliki kesiapsiagaansedang sebanyak $0(0 \%)$, dan 1 orang (16,7\%) lainnyamemiliki kesiapsiagaan tinggi. Berikutnya dari 30 orang petugas yang pengetahuannya cukup, terdapat 7 orang $(23,3 \%)$ dengan kesiapsiagaan rendah, 17 orang $(56,7 \%)$ dengan kesiapsiagaan sedang, dan 6 orang (20\%) dengan kesiapsiagaan tinggi. Selanjutnya dari 34 orang yang pengetahuannya baik, terdapat 10 orang $(29,4 \%)$ dengan kesiapsiagaan rendah, 8 orang $(23,5 \%)$ dengan kesiapsiagaan sedang, dan 16 orang $(47,1 \%)$ dengan kesiapsiagaan tinggi.

Untuk mengetahui hubungan pengetahuan dengan kesiapsiagaan petugas puskesmas dalammenghadapi bencana gempa bumi di wilayah Puskesmas Telaga Dewa Kota Bengkulu digunakan uji Chi- Square (Pearson Chi-Square). Hasil uji 
Pearson Chi-Square didapat sebesar 17.132 dengan nilai asymp.sig $(p)=0,002$. Karena nilai $\mathrm{p}<0,05$ maka $\mathrm{H} 0$ ditolak Ha diterima artinya ada hubungan pengetahuan dengankesiapsiagaan petugas puskesmas dalam menghadapi bencana gempa bumi di wilayah Puskesmas Telaga Dewa Kota Bengkulu.

Keeratan hubungan pengetahuan dengan kesiapsiagaan petugas puskesmas dalam menghadapi bencana gempa bumi di wilayah Puskesmas Telaga Dewa Kota Bengkulu dapat dilihat pada nilai Contingency Coefficient (C). Nilai C didapat sebesar 0,44 . Karena nilai tersebut tidak terlalu jauh dari nilai $\mathrm{C}_{\max }=0,70$ maka hubungan tersebut dikatakan kategori cukup erat.

Hal ini sejalan dengan penelitian Winandar Aris (2017) bahwa responden yang tidak siap dalam menanggulangi bencana gempa bumi persentasenya lebih banyak didapat pada responden dengan pesepsi negatif yaitu 65,4\% dibandingkan dengan responden yang memiliki persepsi positif yaitu $61,5 \%$. Hasil uji statistik diperoleh nilai pvalue $=0,004(\mathrm{p}<0,05)$ yang berarti ada hubungan antara persepsi dengan kesiapsiagaan penanggulangan bencana gempa bumi. Sedangkan Penelitian yang dilakukan oleh Najman (2019), menunjukkan bahwa terdapat hubungan yang bermakna antarapengetahuan dengan kesiapsiagaan petugas kesehatan Puskesmas Biru Kabupaten Bone dalam menghadapi Kejadian Luar Biasa DBD di wilayah kerjanya dengan nilai $\mathrm{p}=0,016(\mathrm{p}<0,05)$.

\section{Hubungan Sikap Dengan Kesiapsiagaan Petugas Puskesmas Dalam Menghadapi Bencana Gempa Bumi}

Pada tabel 5 dapat dilihat, bahwa di Puskesmas Telaga Dewa Kota Bengkulu, dari 18 orang petugas dengan sikap Unfavorable, terdapat 11 orang $(61,1 \%)$ yang memiliki kesiapsiagaan rendah, sebanyak 4 orang $(22,2 \%)$ petugas dengan kesiapsiagaan sedang, dan 3 orang (16,7\%) lainnya memiliki kesiapsiagaan tinggi. Berikutnya dari 52 orang yang merasa sikap favorable, terdapat 11 orang $(21,2 \%)$ dengan kesiapsiagaan rendah, sedangkan 21 orang $(40,4 \%)$ dengan kesiapsiagaan sedang, dan 20 orang(38,5\%) dengan kesiapsiagaan tinggi.

Untuk mengetahui hubungan sikap dengan kesiapsiagaan petugas puskesmas dalam menghadapi bencana gempa bumi di wilayah Puskesmas Telaga Dewa Kota Bengkulu digunakan uji Chi-Square (Pearson Chi-Square). Hasil uji Pearson 
Chi-Square didapat sebesar 9.961 dengan nilai asymp.sig $(p)=0,007$. Karena nilai $\mathrm{p}<0,05$ maka H0 ditolak Ha diterima artinya ada hubungan sikap dengan kesiapsiagaanpetugas puskesmas dalammenghadapi bencana gempa bumi di wilayah Puskesmas Telaga Dewa Kota Bengkulu.

Hal ini dibuktikan dengan adanya keeratan hubungan sikap dengan kesiapsiagaan petugas puskesmas dalam menghadapi bencana gempa bumi di wilayah Puskesmas Telaga Dewa Kota Bengkulu dapat dilihat pada nilai Contingency Coefficient(C). Nilai C didapat sebesar 0,35. Karena nilai tersebut tidak terlalu jauhdari nilai $\mathrm{C}_{\max }=0,70$ maka hubungan tersebut dikatakan kategori cukup erat. Penelitian ini sejalan dengan penelitian yang dilakukan Amelia (2016), hasil penelitian menunjukkan bahwa tenaga kesehatan yang memiliki pengetahuan baik adalah $73,2 \%$ dan pengetahuan kurang sebanyak 26,8\%. tenaga kesehatan yang memiliki sifat baik adalah 58,5\% dan sikap kurang sebanyak 41,5\%. hasil uji chi-square menunjukkan ada hubungan yang signifikan antarapengetahuan dengan sikap tenaga kesehatan tentang pelayanan kesehatan pascabencana $(p=0,001)$. Kesimpulan penelitian ini adalah terdapat hubungan antara pengetahuan dengan sikap tenaga kesehatan puskesmas meuraxa tentang pelayanan kesehatan pascabencana. Hasil penelitian yang dilakukan Najman (2019), menunjukkan bahwa terdapat hubungan yang bermakna antara sikap dengan kesiapsiagaan petugas kesehatan Puskesmas BiruKabupaten Bone dalam menghadapi Kejadian Luar Biasa DBD di wilayah kerjanya dengan nilai $\mathrm{p}=0,006(\mathrm{p}<0,05)$.

Petugas puskesmas harus ditingkatkan kualitasnya mengenai pengetahuan dan sikap dengan kesiapsiagaan dalam mengadapi bencana gempa bumi, melalui prasarana yang memadai, tersedianya tempat pelatihan-pelatihan serta seminar mengenai kesiapsiagaan dalambencana gempa bumi. Sehingga penelitian ini dapat dijadikan acuanuntuk tindakan petugas puskesmas agar dapat cepat dan tanggap dalam menghadapi situasi yang rumit terutama bencana gempa bumi. Petugas puskesmas harus meningkatkan kesadarannya serta memberikan pendidikan kepada masyarakat mengenai siap siaga bencana gempa bumi, sehingga dengan adanya peran utama kepedulian petugas dapat mengurangi dampak serta kepanikan jika terjadinya sebuah bencana terutama bencana gempa bumi. 


\section{KESIMPULAN}

Berdasarkan hasil penelitian hubungan pengetahuan dan sikap dengan kesiapsiagaan petugas puskesmas dalam menghadapi bencana gempa bumi di Puskesmas Telaga Dewa Kota Bengkulu, makadapat disimpulkan bahwa: dari 70 orang petugas puskesmas didapatkan pengetahuan dalam menghadapi bencana gempa bumi 6 petugas $(8,6 \%)$ menilai pengetahuannya kurang, kemudian 30 petugas $(42,9 \%)$ menilai pengetahuannya cukup, selanjutnya sisa petugas ada 34 orang $(48,6 \%)$ baik. Dari 70 orang petugas puskesmas didapatkan sikap dalam menghadapi bencana gempa bumi 18 orang (25,7\%) menilai Unfavourable, sedangkan 52 orang $(74,3 \%)$ menilai Favourable. Dari 70 orang petugas puskesmas didapatkan kesiapsiagaandalam menghadapi bencana gempa bumi 22 petugas $(31,4 \%)$ menilai rendah, kemudian sebanyak 25 petugas $(35,7 \%)$ menilai sedang, sedangkan 23 petugas (32,9\%) menilai tinggi. Ada hubungan antara pengetahuan dengan kesiapsiagaan petugas puskesmas dalam mengahadapi bencana gempa bumi di Puskesmas Telaga Dewa Kota Bengkulu. Ada hubungan antara sikap dengan kesiapsiagaan petugas puskesmas dalam mengahadapi bencana gempa bumi di Puskesmas Telaga Dewa Kota Bengkulu. Ada hubungan antara pengetahuan dan sikap dengan kesiapsiagaan petugas puskesmas dalam menghadapi bencana gempa bumi di Puskesmas Telaga Dewa Kota Bengkulu. 


\section{DAFTAR RUJUKAN}

Bapeda Provinsi Bengkulu. (2002). Laporan Tahunan.

BMKG. (2017). Database Gempa BMKG Kepahiang. BMKG Kepahiang, Bengkulu.

BNPB. (2012). Menuju Indonesia Tangguh Menghadapi Tsunami. Jakarta: Badan Nasional Penanggulangan Bencana.

BNPB. (2019). Indeks Resiko Bencana Indonesia Tahun 2019. Jakarta: Direktorat Pengurangan Risiko Bencana Deputi Bidang Pencegahan dan Kesiapsiagaan.

Dinas ESDM Provinsi Bengkulu. (2003). RP4D Kota Bengkulu.Bengkulu. Dinas ESDM Provinsi Bengkulu.

Heryana, A. (2020). Peran Kesmas Dalam Kesiapsiagaan Terhadap Bencana. Prodi Kesehatan Masyarakat Universitas Esa Unggul.

Mawan. (2019). Hubunga Pengetahuan Dan Sikap Dengan KesiapsiagaanPetugasPuskesmas Dalam Menghadapi Bencana Gempa Bumi Di Puskesmas Betungan Kota Bengkulu. Universitas Tri Mandiri Sakti: Bengkulu.

Nasional, B., Bencana, P., Indonesia, R. B., Bencana, P., Nasional, B., \& rencana, P. (n.d.). I-1 skripsi adaptive village governance ... aisyah nusa ramadhana.

Notoatmodjo, S. 2013. Pendidikan Dan Perilaku Kesehatan. Jakarta:PT Rineka Cipta.

Nurdin. (2017). Kajian Risiko dan Aksi Adaptasi Perubahan Iklim Sektor Spesifik Ketahanan Pangan di Dusun Ngoro-Oro, Desa Giriasih, Kecamatan Purwosari. January.

PPNI. 2013. The Role of The Public Health Nurse In Disaster (Preparedness, Response and Recovery). APHN Public Health Nurse PreparednessCommitte.

Yustisia, N., Aprilatutini, T., \& Utama, T. A. (2019). Pengaruh Simulasi Menghadapi Bencana Gempa Bumi Terhadap Kesiapsiagaan Siswa Sdn 86 Kota Bengkulu. Journal of Nursing and Public Health, 7(2), 32-38. https://doi.org/10.37676/jnph.v7i2.888 